\title{
Medical services at the Olympics: a monumental challenge
}

Published at www.cmaj.ca on Feb. 8

$\mathrm{F}$ or years, Canadians have been regaled with ongoing tales about the challenges of staging the 2010 Winter Olympics in Vancouver, British Columbia, from Feb. 1228. Can the roads handle the anticipated surge in traffic? Can the city fulfill the social pledges that helped it win the bid in the first place? Will security be adequate? Will there be snow in Whistler?

Rarely, though, has the attention been focused on the monumental task of organizing and providing health and medical services for the anticipated 5500 Olympians and officials, 1350 Paralympians, 10000 media representatives, 25000 volunteers, along with the untold tourists who will descend on the province.

Yet, things are well in hand for the influx and the anticipated boom in medical requirements, according to the Vancouver Organizing Committee for the 2010 Olympic and Paralympic Winter Games (VANOC) and local health authorities.

Jack Taunton, chief medical officer for the 2010 Olympics, says organizers sought to structure medical services in such a way as to limit the burden placed on local hospitals.

VANOC will provide care for athletes and the "Olympic family" in a pair of 10 000-square-foot "polyclinics" that have been established in the middle of the action: one in Whistler and another near the Olympic Village and Vancouver's downtown core.

Polyclinics have imaging, laboratory and pharmacy services that will allow them to assess, diagnose, treat and discharge patients, reducing the load on hospitals, says Taunton, who heads a team responsible for coordinating medical services - including antidoping across the province during the Games. "We want to be able to do as much as we can at the polyclinics without hospitalizing people."

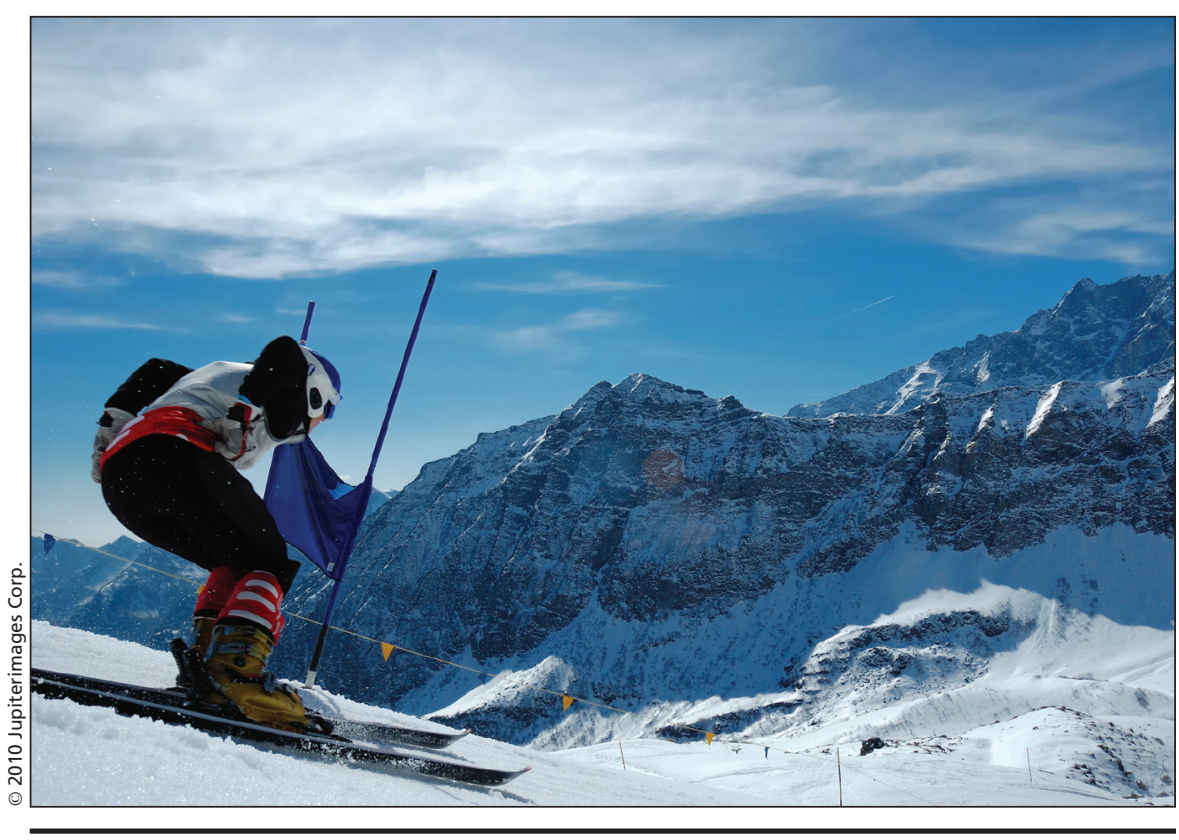

Athletes injured on the ski hills of Whistler, British Columbia, will be treated in a nearby "polyclinic." A second 10 000-square-foot clinic has been established near downtown Vancouver.

But should hospitalization be necessary, the Vancouver General Hospital has been designated the primary provider of care for athletes, with care to be led by a team headed by Vancouver General Chief of Trauma Dr. Ross Brown. The nearby St. Paul's Hospital will be the primary provider of medical services for spectators. But all hospitals in lower mainland $\mathrm{BC}$ will be prepared for "walk-in" athletes, officials, staff and spectators, while all Olympic venues will include treatment areas for both spectators and athletes. Officers will patrol venues to identify individuals needing medical attention.

In a move exceeding preparation at previous Olympics, the Whistler polyclinic has been equipped with a mobile operating theatre, which can be used for rare "life or limb" situations in which an athlete cannot tolerate transport to the Vancouver General, or in the event of mass casualty scenarios. BC Ambulance Services will have ambulances on standby and VANOC will lease two helicopters for the duration of the Games.
Organizers do not anticipate a heavy load. "Overall, people coming to the Olympics tend to be a very healthy population," and therefore host cities do not see a large influx of spectators into local hospitals, says Dr. Patricia Daly, chief medical health officer for Vancouver Coastal Health.

There is typically less demand for health services within the local population during an Olympic Games, because many residents leave for holidays. Organizers will delay $35 \%$ of elective surgeries over a four-week period, in part because many local surgeons are either volunteering for the Games, or would like to attend events, Daly adds. She notes that such delays in elective surgeries are usually not resented by local residents because they often want to travel, avoid traffic congestion or take part in the festivities.

On the public health front, Taunton says that the pandemic (H1N1) 2009 influenza should not pose a problem, although seasonal flu may still be present. To limit the spread, VANOC has 
purchased 5000 doses of seasonal flu vaccine for its staff, while Vancouver Coastal Health is picking up the vaccine tab for an estimated 20000 volunteers.

Organizers have also planned a series of measures to ensure air, water and food quality, as well as prevent disease outbreaks.

Taunton says air quality will be monitored at both indoor and outdoor venues. And to prevent asthma and exerciseinduced asthma, VANOC has purchased 19 electric ice shavers to replace the traditional propane powered zambonis.

Water quality will be monitored in both Vancouver and Whistler, while food inspection officials will regularly inspect local eateries and restaurants to prevent the spread of enteropathic illnesses, such as Norwalk virus. Disease and injury reports from all hospitals, polyclinics and Olympic venues will be tracked and made available on the VANOC website.

So extensive appear the preparations that Perry Kendall, BC's provincial health officer, says VANOC and Vancouver Coastal Health have "set new standards for completeness and integration" compared with organizers of previous Olympic Games.

With athletes having proven in the past that they do not distain parties in the Olympic village, organizers will also distribute more than 100000 condoms at polyclinics and designated Olympic hotels, and offer free HIV testing to athletes and their families.

Funding, though, has presented a bit of a problem, in part because of unfulfilled promises. In 2003, the BC gov- ernment agreed to donate $\$ 12$ million to cover emergency medical services and equipment, promising to provide that money in 2010 dollars to account for inflation. That promise wasn't fulfilled, and organizers say they've had to scramble to cover the difference.

Olympic sponsors have covered some of that shortfall, while others have donated equipment, including eyeglasses, contact lenses, knee braces and ultrasound machines. Ownership of some of the equipment will remain with the province after the Games, but other bits and pieces will be returned to donors to be resold at reduced prices.

In the run-up to the Games, organizers also promised increased investment for public health, public transit and social housing for Vancouver residents, particularly in low-income neighbourhoods.

But promises offered in such agreements as the Inner City Inclusive Commitment Statement (http://vancouver.ca /commsvcs/housing/sra/pdf/statement .pdf) have not been honoured, some observers say. They also fear that Vancouver may follow the lead of Atlanta, Georgia, in 1996, where various forms of legislation were used to essentially criminalize homelessness and remove homeless people from the streets for the duration of the Games.

The homeless crisis has not been properly dealt with, says Judy Graves, outreach coordinator for the city of Vancouver's housing department. There has been an increase in the incidence of ticketing directed at Vancouver's homeless over the past few years, with people being ticketed up to $\$ 173$ for sleeping in public places, selling goods or urinating in public.

Organizers, though, hope the legacy of these Games will be more favourable. They note that Vancouver's Homeless Emergency Action Team set up five shelters last year, which brought in an average of 439 homeless per night. This year, four shelters have been established. Graves believes the shelters would not have opened without the Olympics. She also notes that Vancouver's Downtown Business Improvement Association has reported decreased levels of panhandling in the area.

Taunton adds that broader health infrastructure and human resources benefits will accrue to Vancouver communities long after the Games are over. The Whistler mobile medical clinic, for example, will continue to provide services to rural and underserved communities, and during emergencies. A computed tomography machine purchased for the Whistler polyclinic will remain in place, allowing the ski hill to finally assess head injuries onsite. The Richmond Speed Skating Oval will become a sports, health and wellness facility. As well, medical staff across the province will have the benefit of having been trained to deal with mass casualty situations and natural disasters. - Neda Amiri and Goldis Chami, Vancouver, BC

DOI:10.1503/cmaj.109-3170

Neda Amiri and Goldis Chami are medical students at the University of British Columbia 